that we have achieved within the B.M.A. a fairer and more realistic system of negotiation for junior staff let us learn a lesson from our colleagues in general practice who have been longer at the game. Surely one of the main reasons that they find themselves in their present difficulties is that they have not been able to present a united body of opinion to the Government.

I would like to point out that the hospital service consists of consultants and junior staff, and that we are all in the same boat. Dr. Hession has suggested that the consultants cannot reasonably be expected to negotiate on our behalf, as they are our employers. What nonsense! Consultants may select their junior staff, but this has nothing to do with employment, salary scales, or conditions of service, which are ultimately the prerogative of the Government. The consultants are inevitably affected by the present problems of hospital junior doctors, and realize I am sure that in supporting our present efforts they can benefit only themselves.

Dr. Hession has claimed that his independent group will have direct access to the Minister of Health, and will be looked upon as the official negotiating body of hospital junior staff. I would point out to Dr. Hession that the general practitioners have already tried a similar manœuvre, and yet it is quite obvious that the Minister still considers the B.M.A. the official negotiating body for that section of the profession. The independent Action Group have not suggested or achieved anything which has not already been dealt with by the B.M.A. Hospital Junior Staffs Group, and I feel sure that the former came into existence only because of the latter's regrettable failure to communicate its work to the hospital junior doctors.

Now is not the time to create a further split in an already sadly divided profession. The consultants have shown that they realize that our problems are theirs and are willing to support us through the present recognized negotiating machinery. I am sure a combined appeal by all grades of hospital medical staff to the Review Body and the Minister will achieve far more both now and in the future than any attempts to form a splinter group.

Divide and rule may be an old cliché, but nevertheless a true one and well worth consideration by Dr. Hession and his supporters. -I am, etc.,

St. Mary's Hospitals,

W. R. HutToN.

Manchester 1.

SIR,-According to Dr. E. A. HarveySmith (Supplement, 8 January, p. 9) the Joint Consultants Committee is an autonomous negotiating body acting on behalf of all hospital doctors. On p. 10 we learn that on the Joint Consultants Committee the Central Consultants and Specialists Committee of the B.M.A. is the junior partner to the Royal Colleges.

It seems doubtful, therefore, if junior hospital doctors can ever secure adequate and effective representation of their views while the Royal Colleges can dominate negotiations with the Minister. It seems strange, too, that democratically minded Ministers should continue to negotiate with a committee dominated by unrepresentative bodies.

Every year at the Annual Representative Meeting there is a motion which renews the autonomous powers of the Central Consultants and Specialists Committee. The way is now open for some junior hospital doctors to persuade either their Division or the Junior Members Forum to prepare an appropriate amendment to this motion and to move it at Exeter in July.-I am, etc.,

$$
\begin{aligned}
& \text { Claverdon, } \\
& \text { Warwickshire. }
\end{aligned}
$$

The Second Report

SIR,-It is disappointing to note that the lecture delivered by Sir George Godber on 15 March 1965 at Aberdeen, and published in the British Medical fournal on 18 September, p. 665, should have aroused so little comment. This was one of the first opportunities that many of us must have had to read the considered views of a senior official in the Ministry of Health on the present problems which beset the National Health Service.

Many will agree with Sir George that grea changes must take place in the field of general practice if in the future the family doctor is to offer an increasingly effective service to the public-and at the same time derive any satisfaction for himself in so doing. The point to be emphasized, however, is that proposals for such changes must come from within the profession and not be imposed upon it from without.

Much of our hopes for the future depend on the current negotiations which are proceeding on the charter for general practice. All must admit that this document contains little that will fundamentally alter the present form of general practice, or adapt it to meet the medical needs of the future.

Much stress has been laid on the need to modernize the premises of the general practitioners and to supply them with the necessary ancillary help-but will such expense be justified if these "surgery services" are only available to the public for three to four hours each day

A new look should be taken at the tradition of the doctor's day. Patients should be seen at their convenience, by appointment, throughout the day at the surgery. Why are patients having to crowd themselves into a morning of evening surgery session - or failing this to reques a home visit for what often amounts to a mino ailment, or even just to obtain a certificate?

Great economies could be effected in the use and employment of staff and the servicing of the surgery premises. New fields could be opened for collaboration with the services of the local health authority. There would be a great saving of time and frustration for the doctor-not to mention the benefit that would accrue to the public.

With the development of group practice systems these things are within our grasp. What is it that holds us back? Is it lack of good will or money-or could it be fear of change in an ageing population of general practitioners ?

It has been well said that sooner or later general practice will have to be taken and dragged screaming into the twentieth century. How can 23,000 confirmed individualists, whose accepted standards and content of service are subject to such wide variations, ever make progress without a strong lead and towards a clear, well-defined obiective ?

The B.M.A. seems reluctant, through its principal officers and committees, to commit itself or its members to any far-reaching change in the form of general practice. Yet the profession is as hungry for leadership as it is in need of a just system of remuneration. Too much attention hạs been focused over these long barren years on payment. More than money is needed.
There must be a belief in the system and a sense of dedication to make it work. This is where the Association finds itself in a dilemma, for are we not ruled by a group of elderly rebels -to the N.H.S.? Men and women who have been mulling over these problems for the past 20 -odd years are unlikely at this juncture to produce any worth while contribution for the developments that the future demands.

They are used to much speaking, as the published accounts of their debates in committee or council well illustrate, but their thoughts are confused and rigid, and new ideas penetrate but little. They look backwards over their shoulders to the imaginary glories of the past, while they remain blissfully unaware of the broad uplands of the future towards which many younger members of the Association would wish that they were setting a course.

-I am, etc.

Birmingham 30 J. K. H. McCullough.

\section{Consumers' Association}

SIR,-May I point out that the Consumers' Association, publishers of Which ?, has never asked the B.M.A. for a list of doctors' addresses (Editorial comment in letters, 1 January, p. 54) ? Should we wish to mail doctors with our material we acquire and pay for appropriate lists from a mailing house.

The publication mentioned by your correspondent was produced, as he said, by the Government-sponsored Consumer Council.I am, etc.,

\section{London W.C.2.}

Lucille Hall, Press Officer

${ }^{* *}$ We apologize for the confusion.-ED. B.M.F.

\section{Methyldopa and Haemolytic Anaemia}

SIR,-In the past year the attention of the Committee on Safety of Drugs has been drawn, by doctors or by the manufacturers of the drug, to nine cases of haemolytic anaemia occurring in patients treated with methyldopa (Aldomet).

At this stage the reports do not constitute evidence of a causal relationship, and the number of reports is very small in relation to the usage of the drug. Nevertheless, if doctors encounter patients under treatment with methyldopa who have symptoms and signs which might be due to haemolytic anaemia they are requested to report details of such patients to the Committee on the yellow " early warning cards."-I am, etc.

$$
\begin{aligned}
& \text { D. A. CAHAL, } \\
& \text { Medical Assessor. } \\
& \text { Committee on Safety of Drugs, } \\
& \text { Queen Anne's Mansions, } \\
& \text { Queen Anne's Gate, } \\
& \text { London S.W.1. }
\end{aligned}
$$

Corrections. - We regret that in the letter by Mr. W. J. W. Sharrard (8 January, p. 105) there was a misprint at the end of the second paragraph. The sentence, "It is for this reason that $I$ and my colleagues have advised again the indiscriminate use of A.T.S." should have read

"have advised against the indiscriminate use of A.T.S."

In the third paragraph of the letter by $\mathrm{Dr}$. D. Millington (1 January, p. 49) there was sentence reading ".. the only objective finding being a slight diffuse infection of the pharynx." This should have read "... injection of the pharynx." 